\title{
A PUZZLE ON HOW BUSINESS GRADUATE PERCEIVE MIS MAJOR IN KUWAIT: PERSPECTIVE FROM AN ARAB COUNTRY
}

\author{
Kamel Rouibah, College of Business Administration, Kuwait University, krouibah@cba.edu.kw \\ Abeer A. Al-Hassan, College of Business Administration, Kuwait University, abeer@cba.edu.kw
}

\begin{abstract}
This study aims to measure the perception of MIS graduates of Kuwait University towards their major after they joined the labor force. It seeks to look at the factors that may lead to their satisfaction or dissatisfaction. To achieve these objectives, the study used a mix method of qualitative and quantitative approach. The first was using the KJ method that included two focus groups (with 10 MIS graduates), whereas the other type was an open ended section of the quantitative part of the study. 105 questionnaires were completed. The results of the first set revealed satisfaction and dissatisfaction were related to the following categories: hard skills/ technical skills; soft skills or skills learned; work environment; perspective of post graduate studies; MIS identity crises; and relevancy of MIS major. The quantitative analysis revealed about $55 \%$ of correspondence were satisfied, $20 \%$ were dissatisfied whereas the rest were neutral.
\end{abstract}

Keywords: MIS careers, MIS Graduates, Graduate Satisfaction, Graduate Dissatisfaction, MIS Skills Perception, Soft Skills, Technical Skills

\section{INTRODUCTION ON RESEARCH MOTIVATION}

Information systems (IS) are the use of a company, non-profit or governmental organization information technology to support its business processes in order to achieve its operational excellence and competitive advantages. In order to achieve this mission IS professionals must focus on understanding technical, organizational and human factors that may affect the development, use and ongoing support of IS. Therefore they serve as the communication bridge between the information system developer (technical) and end-user communities within an organization.

A majority of IS programs are attached to business administration schools and have different names such as management information systems, computer information systems, business information systems or information management. All these programs combine both business and technical courses, but the amount of emphasis between the business and technical varies among these programs. For example the program of management information system (MIS) emphasizes more the business part than does the computer information system. In addition, while the knowledge of technology, including programming is part of the MIS curriculum, programming is however just a small part. In addition to MIS courses, students take core business courses such as, economic, finance, management, accounting, and operation management. There are many jobs related to MIS where students do not program. During the curriculum MIS students learn how organizations use IS to improve business processes, how to manage various resources including (information systems, hardware and software) in order to best serve the needs of different beneficiaries of information systems such as operational level staff, middle managers, senior executives, customers, suppliers and other partners. MIS students may also learn also how to develop new information systems, database management information systems to store and retrieve data. They learn also how to set up different networks in order to integrate different systems and ensure their security. In addition to the MIS program, other alternatives and competing programs exist in other colleges such as computer sciences, computer engineering and information sciences as the case at Kuwait University. These programs have more focus on software programming through logic/procedure than does MIS. One major difference between MIS and Computer Science is that MIS focuses on the whole organization whereas the later focuses only on the software. Therefore when MIS students graduate they might face potential job competition in order to get recognition about their status despite the differences among these programs. 


\section{Issues in Information Systems \\ Volume 17, Issue III, pp. 48-58, 2016}

The MIS field is facing radical changes. In the past, its main role consisted to develop information systems, and then changed to delivering IT support. However, nowadays these roles have shifted toward a service role and supporting intra and inter-organizational business processes through outsourcing and buying ready-made software packages. This new role has led to the creation of panoply of jobs, which in theory, enable graduate students to fulfill. The jobs the researchers were able to find in US books and IT professional magazines include business analyst, systems analyst, database administrator, database analyst, programmer, web developer, software vendor, IT consultant, technical support specialist, business application developer, project manager, business intelligence analyst, systems developer, network administrator, information systems manager, information security specialist, etc. All these jobs require diverse skills, which were classified in different categories such as human job skills, business skills, interpersonal skills and technical skills (Huang, et al., 2009; Joshi, et al., 2010).

The need for well-educated professionals in the field is the basis for a strong link between educational programs and the market (Abraham, et al., 2006; Dick, et al., 2007), which motivates this study toward understanding factors that affect graduate satisfaction in the MIS field in Kuwait.

\section{Research questions and objectives}

In Kuwait, many of IS jobs are occupied by a large number of well-qualified expatriates, this constitute high competition and threats for local graduates when they target the private sector. Linked to this Joshi et al. (2010) observed that while various stakeholder groups simply expect contemporary IT professionals to know more and be able to do more than in the past, scholars report differences in the way that respondent groups value the importance of IT job skills. For example Green (1989) found that systems analysts primarily valued their non-technical roles and skills while users ascribed greater importance to the analysts" technical skills". In line with previous studies that focused on the perceptions of employees in the IS field about their skills, this study aims to focus on the following question related to MIS jobs and skills from the point of view of MIS graduates. This paper focused on graduate satisfaction in the market place and aims to understand factors that surround graduate satisfaction or dissatisfaction with their major after joining the labor force

While many studies focused on what is MIS major, how it attracts potential students, and describe needed skills, the perceptions and satisfaction of graduates with the degree and skills especially in developing countries has not yet been studied empirically. In line with previous studies that analyze perceptions of IS employees about their skills with regard to the market needs, the current study portrays a number of issues related to MIS graduate in their workplace in Kuwait, an Arab country through the following questions:

1. Are MIS gradates satisfied with their major, i.e. are skills they acquired during the MIS program allow then to fulfill their job needs?

2. To what extent do MIS graduates believe that their major well prepared them to the job career/ market?

3. Do MIS graduates recommend the MIS Major to their family members and friends?

4. To what extent the MIS Major was effective according to MIS graduates?

5. To what extent do graduate students assess the importance and satisfaction of different skills acquired during the MIS curriculum (technical, analytical, interpersonal and communication)?

\section{LITERATURE REVIEW}

Several studies focused on different issues related to MIS in the workplace. Some studies examined trends in skills required for the job. These studies typically assess skills needed for IT jobs including software developers (Simmons, 2010). Other researchers surveyed past studies related to the "gap skills" between theory and actual skills needed by the market and identify knowledge deficiencies Radmermacher, et al., 2014).

More studies focused on factors that lead to graduate satisfaction and dissatisfaction (Benamati, et al., 2013; 0 et al., 2013). For example, Radermacher and Walia (2013) conducted a literature review in order to identify knowledge deficiency, which they describe as "any skill, ability, or knowledge of concept which a recently graduated student lacks based on the expectations of industry or academia." Radermacher et al. (2014) interviewed twenty three 
managers in the United States and Europe who are responsible for hiring new graduates in order to find out what areas usually young graduates struggled with, which skills they lacked and what may prevent them from getting hired.

With regard to previous studies, the current study fits within the last category. In addition to this, a comparison to western studies is possible since there is little or no studies focused on the MIS graduate perceptions in the Arab world as of this research. For example, Al-Imamy and Farhat (2005) focused only technical skills required by the market in order to modify the MIS major. MEED (Pepper, 2007) conducted a survey about the perceptions of employment with regard to local graduate students from the business universities in the Gulf Cooperation Council. The results reveal that $72 \%$ of senior executives believe the main obstacles to hiring graduates consist of their lack of required skills and qualifications. $50 \%$ believe high salary expectations of graduates are serious problems. And $40 \%$ say that graduates have an unethical approach vis-à-vis of their work. Buarki et al. (2011) investigated the state of the art of skills needed by students enrolled in library and information system (LIS) in Kuwait as well as analyzing job market. Rouibah (2012) investigated motives that lead undergraduate's students at Kuwaiti university to select the MIS major. Using a qualitative approach with a sample of 195 students he identified thirteen drivers toward the major. These are: characteristics of the major and the curriculum, positive perceptions about MIS instructors, social influence, self-efficacy, matching with interest, job characteristics, job availability, financial consideration, information search, attitude, enjoyment, and curiosity.

\section{RESEARCH METHODOLOGY}

This study used a mix research approach that combines both qualitative and quantitative data collection to investigate issues related to MIS graduate at their workplace.

The first qualitative approach involves data collection related to how MIS graduate perceive the value of MIS major after they graduate, whether they are satisfied or dissatisfied, and factors that affect their satisfaction at the workplace and their perceptions about the skills they acquired during the major. Data collections were done using the KJ method, which derive its name from his Japanese creator Dr. Kawakita Jiro. This is a business methods used to organize ideas and data. It is one of the most used management and planning tools in Japan. KJ method is a technique of "mind-mapping" also known as the affinity diagram that allows to answering complex questions. The process goes through various phases, starting from problem formation; that is the act of identifying and defining a problem, through thinking activities. This step is done with a clear definition of the problem. For example, what is the cause of traffic in Kuwait?) Brainstorming ideas comes next. There are several ways for which the ideas could be organized.

The method passes through six steps. In step1, focus questions were determined: How MIS graduate thinks about the skills they get after they graduate from their business school? In step 2, groups of participants are organized. The researchers formed two focus groups of MIS employees who graduated from a leading business school in Kuwait, each composed of five graduates. The average experience of the first group is 2.7 years while the second is 5.2 years. In step 3, opinions of participants are put onto sticky notes. In step 4, sticky notes are put on the wall in a random order; each participant puts his/her sticky notes up on the wall, which can then be read by other participants, and this stimulates other contributions. In step 5, similar items are grouped and merged. Once everyone has had a chance to add their contributions to the wall, the facilitator instructs the group to start grouping like items in another part of the room. During the last step (6) participants give names to grouped items. Table 1 and Table 2 has some demographics on participants.

Table 1. Demographics of focus group [A] and Group [B]

\begin{tabular}{|c|c|c|c|c|c|}
\hline Participants & Gender & Year Of Graduation & \multicolumn{1}{|c|}{ Place of Work } & Position & Years of Experience \\
\hline Group A & & & & & \\
\hline P1 & M & 2012 & University & $\begin{array}{l}\text { System } \\
\text { Admin }\end{array}$ & 2 \\
\hline
\end{tabular}




\begin{tabular}{|c|c|c|c|c|c|}
\hline $\mathbf{P 2}$ & $\mathrm{F}$ & 2011 & IT & Analyst & Less than a year \\
\hline P3 & $\mathrm{F}$ & 2006 & Bank & $\begin{array}{l}\text { MIS } \\
\text { Officer }\end{array}$ & 6 years \\
\hline P4 & $\mathrm{F}$ & 2011 & University & $\begin{array}{l}\text { Teaching } \\
\text { Assistant }\end{array}$ & 2 \\
\hline P5 & M & 2011 & Telecommunication & $\begin{array}{l}\text { IT support } \\
\text { specialist }\end{array}$ & 2.5 \\
\hline \multicolumn{6}{|c|}{ Group B } \\
\hline P1 & $\mathrm{F}$ & 2007 & Public institution & $\begin{array}{l}\text { Financial } \\
\text { Researcher }\end{array}$ & 6 \\
\hline $\mathbf{P 2}$ & $\mathrm{M}$ & 2010 & Ministry & IT support & 8 \\
\hline P3 & $\mathrm{M}$ & 2007 & Bank & $\begin{array}{l}\text { IT Security } \\
\text { Officer }\end{array}$ & 6.5 \\
\hline P4 & $\mathrm{F}$ & 2009 & Oil company & $\begin{array}{l}\text { Senior } \\
\text { Technical }\end{array}$ & 5 \\
\hline P5 & $\mathrm{F}$ & 2013 & Research institute & $\begin{array}{l}\text { System } \\
\text { analyst }\end{array}$ & 5 months \\
\hline
\end{tabular}

The second quantitative study consisted of a survey with an open-ended section in which respondents were asked to list their perceptions about the MIS program in a generic fashion. The survey included many questions for correspondence. For the purpose of this paper we will only focus on that part of the survey that addresses our research questions such as (1) Demographic data of the quantitative study (age, citizenship, gender, educational level, Year since graduation, (2) degree of satisfaction they have with their major, (3) extent to which their major well prepared them to the job career/ market, (4) intent to recommend the MIS major to their family members and friends, and finally (4) extend that the MIS major was effective according to their perceptions. Participants were invited to give their responses in English since it is the official language of teaching at the College of Business Administration - Kuwait University. The questionnaire was distributed to graduates from this college (more than 500 surveys were sent). However, only 108 participated and 105 were completed in this quantitative study.

\section{Results of the Qualitative Data}

\section{RESULTS}

The following table provides results related to factors that lead to satisfactions and dissatisfactions of participants in the two focus groups

Table 2. Identified Items by Group [A]

\begin{tabular}{|c|c|c|}
\hline Groups & Dissatisfaction (D) / Satisfaction (S) & Statement \\
\hline \multirow[t]{2}{*}{$\begin{array}{l}\text { Hard skills (technical } \\
\text { skills }\end{array}$} & Dissatisfaction (D) & $\begin{array}{l}\text { - } \text { More programming. Language (like } \\
\text { C++, Java) are needed } \\
\text { - More technical courses } \\
\text { - Very little knowledge in Networking is } \\
\text { covered } \\
\text { - Use of old programming language } \\
\text { - Need advanced MS Excel teaching } \\
\text { - Need more teaching of SQL for } \\
\text { databases } \\
\text { More emphasis on computer based } \\
\text { skills }\end{array}$ \\
\hline & Satisfaction (S) & - Good skills in VB. Net \\
\hline
\end{tabular}




\begin{tabular}{|c|c|c|}
\hline & & $\begin{array}{l}\text { - } \text { Good IT general knowledge } \\
\text { - Effectiveness in database creation and } \\
\text { maintenance } \\
\text { - Good foundations in programming logic } \\
\text { - Solid system analysis and design }\end{array}$ \\
\hline \multirow[t]{2}{*}{$\begin{array}{l}\text { Soft (non-technical) } \\
\text { skills learned }\end{array}$} & Dissatisfaction & $\begin{array}{l}\text { - Good preparation of business contracts } \\
\text { with outsourcing companies } \\
\text { - Good writing of technical and business } \\
\text { documents } \\
\text { - Critical problem solving } \\
\text { - Good idea presentation for superiors to } \\
\text { get project sponsored }\end{array}$ \\
\hline & Satisfaction & $\begin{array}{l}\text { - Understanding the business } \\
\text { requirements } \\
\text { - Implementation of business processes } \\
\text { management } \\
\text { - Good presentation skills } \\
\text { - Good managerial skills } \\
\text { - Good communication skills } \\
\text { - Good team leadership skills } \\
\text { Good analytical skills }\end{array}$ \\
\hline \multirow[t]{2}{*}{ Work environment } & Dissatisfaction & $\begin{array}{l}\text { - Concerns about work ethics in the MIS } \\
\text { field workplace. } \\
\text { - We have two bosses. } \\
\text { - Sudden and Wasta (promotions (based } \\
\text { on relationship - Nepotism or } \\
\text { cronyism). } \\
\text { - Many competitors in the job market } \\
\text { (especially well qualified Indian Expats } \\
\text { who get cheaper salaries compare to } \\
\text { citizens). } \\
\text { - Threats of outsourcing IT activities in } \\
\text { most companies. } \\
\text { - Instable workplace policies and rules. } \\
\text { - Unproductive and failure projects that } \\
\text { involves MIS and other departments. } \\
\text { - Team works problems, i.e. how to deal } \\
\text { with people who avoid work and } \\
\text { contribution } \\
\text { - Dealing with bad attitude. } \\
\text { - Dealing with inexperienced people. }\end{array}$ \\
\hline & Satisfaction & $\begin{array}{l}\text { - It easy to get a job after graduation } \\
\text { - Good salary } \\
\text { - Understanding of marketing through IT } \\
\text { perspective. }\end{array}$ \\
\hline \multirow[t]{2}{*}{$\begin{array}{l}\text { Perspective of post } \\
\text { graduate studies }\end{array}$} & Dissatisfaction & $\begin{array}{l}\text { - Available IT masters at the business } \\
\text { college is not for MIS graduates. } \\
\text { - There are few professional certifications } \\
\text { available for graduates in Kuwait. } \\
\text { - Need to market MIS major more. }\end{array}$ \\
\hline & Satisfaction & - $\mathrm{N} / \mathrm{A}$ \\
\hline
\end{tabular}


Results of the second focus group reveal the following results

Table 3. Identified Items by Group [B]

\begin{tabular}{|c|c|c|}
\hline Categories & Dissatisfaction (D) / Satisfaction (S) & Items \\
\hline \multirow{10}{*}{$\begin{array}{l}\text { General Public } \\
\text { Misconceptions of } \\
\text { MIS (MIS Identity } \\
\text { Crisis) }\end{array}$} & \multirow[t]{9}{*}{ Dissatisfaction } & $\begin{array}{l}\text { - System analysis job is available only in } \\
\text { few organizations. }\end{array}$ \\
\hline & & $\begin{array}{l}\text { - Organization do not know what's MIS, } \\
\text { it's all IT. }\end{array}$ \\
\hline & & $\begin{array}{l}\text { - I sometimes regret that I have chosen this } \\
\text { MIS field, because it is not well } \\
\text { perceived }\end{array}$ \\
\hline & & $\begin{array}{l}\text { - Disconfirmation between what was being } \\
\text { taught and what being seen in the } \\
\text { workplace: learning skills in business } \\
\text { schools do not apply in real word. }\end{array}$ \\
\hline & & $\begin{array}{l}\text { Not expecting to see young MIS } \\
\text { Kuwaitis in this field }\end{array}$ \\
\hline & & $\begin{array}{l}\text { - Waste Problem - Not putting the right } \\
\text { persons in the right workplace }\end{array}$ \\
\hline & & $\begin{array}{l}\text { Crisis of MIS identify: The } \\
\text { Misconceptions about the field of the } \\
\text { MIS field, and the government and } \\
\text { private Sector do not understand the MIS } \\
\text { fields }\end{array}$ \\
\hline & & $\begin{array}{l}\text { - I love MIS major but the market does not } \\
\text { need it }\end{array}$ \\
\hline & & $\begin{array}{l}\text { - Lack of knowledge about MIS in Kuwait } \\
\text { Market. }\end{array}$ \\
\hline & Satisfaction & - $\mathrm{N} / \mathrm{A}$ \\
\hline \multirow{10}{*}{ Workplace Conditions } & \multirow[t]{7}{*}{ Dissatisfaction } & - MIS graduate lack of technical skills. \\
\hline & & - No database uses \\
\hline & & - Redundancy of data in different systems. \\
\hline & & $\begin{array}{l}\text { - Sometimes organizations stick to the old } \\
\text { manual ways, and there is no will and } \\
\text { motivation to change processes }\end{array}$ \\
\hline & & $\begin{array}{l}\text { - I won't accept to working in any } \\
\text { department, except IT. }\end{array}$ \\
\hline & & - Un-organized work structure. \\
\hline & & $\begin{array}{l}\text { - I am unhappy at my workplace because I } \\
\text { am using paper document instead of } \\
\text { digital means }\end{array}$ \\
\hline & \multirow[t]{3}{*}{ Satisfaction } & $\begin{array}{l}\text { - When I entered my organization (Kuwait } \\
\text { Institute for Scientific Research) I found } \\
\text { out that I have more experience in IT } \\
\text { than my manager }\end{array}$ \\
\hline & & - Very satisfied with my major in MIS. \\
\hline & & $\begin{array}{l}\text { - MIS is very important in my } \\
\text { organization. }\end{array}$ \\
\hline
\end{tabular}




\begin{tabular}{|c|c|c|}
\hline & & $\begin{array}{l}\text { - I am very efficient since I am the boss of } \\
\text { IT issues }\end{array}$ \\
\hline & & $\begin{array}{l}\text { I know more than others, i.e. I know } \\
\text { what others don't know. }\end{array}$ \\
\hline & & $\begin{array}{l}\text { My managers treats me with more } \\
\text { respect when he knew my MIS major }\end{array}$ \\
\hline & & $\begin{array}{l}\text { Employees approach me any time a } \\
\text { problem related to computer or mobile } \\
\text { device applications occurs. }\end{array}$ \\
\hline & & - IT can lead and train others \\
\hline & & $\begin{array}{l}\text { - MIS made me open-minded about new } \\
\text { ideas in workplace }\end{array}$ \\
\hline & & $\begin{array}{l}\text { - MIS interferes with people from all } \\
\text { departments, who they need my help. }\end{array}$ \\
\hline & & $\begin{array}{l}\text { - } \begin{array}{l}\text { There is lot of creativity at my } \\
\text { workplace. }\end{array} \\
\end{array}$ \\
\hline & & - I am in love with MIS. \\
\hline & & - I felt unique in my organization \\
\hline & & - I am consultant within my organization \\
\hline & & - MIS made me brave in front of managers \\
\hline & & $\begin{array}{l}\text { - MIS major helps me a lot with my } \\
\text { regional and international projects }\end{array}$ \\
\hline & & - MIS made me think logically. \\
\hline & & $\begin{array}{l}\text { - MIS helps understanding things related } \\
\text { to systems at work that a lot of } \\
\text { employees don't know. }\end{array}$ \\
\hline & Satisfaction & $\begin{array}{l}\text { The system analysis and design and } \\
\text { programing most relevant courses I } \\
\text { benefits rom in my workplace are system }\end{array}$ \\
\hline & & $\begin{array}{l}\text { I worked in different fields and MIS } \\
\text { helped me to corporate effectively with } \\
\text { them all. }\end{array}$ \\
\hline & & $\begin{array}{l}\text { A major that has focus on many other } \\
\text { subjects such as: finance, risk and } \\
\text { management. }\end{array}$ \\
\hline & & - MIS is the backbone of all majors. \\
\hline Relevancy of MIS & & $\begin{array}{l}\text { - Data analysis done by MIS is important } \\
\text { and essential for decision making. }\end{array}$ \\
\hline major & & - I loved system Analysis and design most. \\
\hline & & $\begin{array}{l}\text { - System analysis and design courses } \\
\text { helped most to solve problems in my } \\
\text { organization. }\end{array}$ \\
\hline & & $\begin{array}{l}\text { MIS is a major that in inter-disciplinary } \\
\text { by nature and focuses on many other } \\
\text { subjects including finance, risk and } \\
\text { management. }\end{array}$ \\
\hline & & $\begin{array}{l}\text { - In my family I am the network } \\
\text { consultant. }\end{array}$ \\
\hline & & $\begin{array}{l}\text { - I like that I have learned IT and } \\
\text { management. }\end{array}$ \\
\hline
\end{tabular}




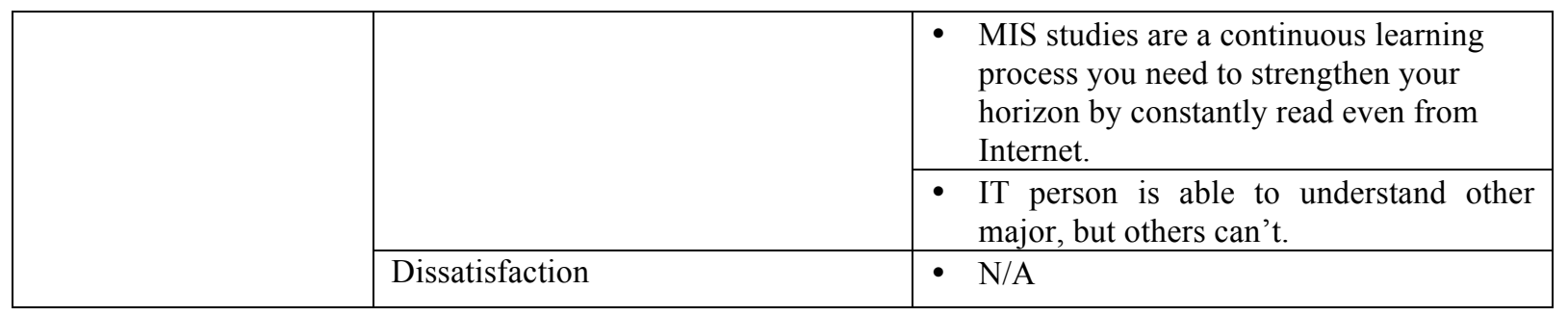

The qualitative data showed interesting results. The focus group participants came up with elements that felt were important to address when discussing MIS major and workplace. Group [A] resulted with 4 elements: hard skills (Technical Skills), soft skills (non-technical skills), work environment, and perspective of postgraduate. Group [B] resulted with the following: general public misconception of MIS, workplace conditions and relevancy of MIS major to their job.

Referring to table 2, we notice that participants were satisfied with the basic knowledge received in their undergraduate such as - good foundation in programming logic, good IT knowledge, effective creation of database creation and maintenance. On a different note they felt that the program/curriculum is not updated. They expressed the need of more programming languages (C++, JAVA) and more networking experience and high emphasis on advanced basic skills such as (MS Excel).

In reference to the soft skills, even though they were highly satisfied with soft skills such as - presentation, managerial, communication, team and leadership, and analytical skills - they expressed the lack of specific skills in technical and business documents. They felt that they were not well prepared in drafting business contracts for outsourcing companies in addition for the need to be taught on hoe to draft a well-developed presentation for superior to get project sponsored.

The work environment/work conditions was an item that was of high concern for both focus groups [A \& B]. Even though both focus on work environments and conditions Group A focused on the big picture of the organization with sub-items such as work ethic in the MIS department, Wasta in the hiring and promotion process. They also mentioned that expats with more experience and less pay threatens their position, threats of outsourcing, and instable work policies. Group B focused on the data/information systems in the organization. They felt that there is still high use of old, manual systems. Redundancy of data in different system was very common concern of Group B. Group B showed more satisfaction in this work environment/work condition. They felt they were important members in their organizations. They also felt that they were treated with respect. In addition they felt unique and that they are the ones to get approached by all employees for help or advice.

Another element that raised concern in the data was participants felt that there are no available post graduate programs. In this category there were no satisfactions.

General public misconception of MIS was also an element concerned in Group B. Table 3 shows the rest of the items. The participants felt that system analysis is a job in few organizations. They claimed that the workforce is not ready to expect to see young MIS Kuwaiti graduates in this field that is dominated by expats. Crise of MIS identity was expressed as well as feeling that there is still lack of knowledge of the MIS field.

Finally, there were dissatisfied comments in the soft skills expressed by group [A] but group [B] felt that the skills and knowledge learned were very satisfactory with relevance of MIS major. The highest praise was on the system analysis and design course and programming logic. They felt that MIS was the backbone of many fields, they felt that they were able to understand all business needs and implement good systems and IT knowledge for data analysis. This element had no dissatisfaction. 


\section{Results of the Quantitative Data Collection}

The following table demonstrated the demographic data of the quantitative study.

Table 4. Demographic Data of the Survey

\begin{tabular}{|l|l|c|c|c|c|}
\hline & & Min & Max & Avg & Stdv \\
\hline & Age & 22 & 45 & 28.5 & 4.54 \\
\hline Citizenship & $\begin{array}{l}\text { Experience in the job } \\
\text { (number years) }\end{array}$ & 2 months & 16 years & 3.06 & 3.38 \\
\hline & Kuwaiti & Frequency & Percent & $\begin{array}{c}\text { Valid } \\
\text { Percent }\end{array}$ & $\begin{array}{c}\text { Cumulative } \\
\text { Percent }\end{array}$ \\
\hline & Non-Kuwaiti & 90 & 83.3 & 85.7 & 85.7 \\
\hline Gender & & 15 & 13.9 & 14.3 & 100.0 \\
\hline & Male & 37 & 34.3 & 35.2 & 35.2 \\
\hline $\begin{array}{l}\text { Educational } \\
\text { level }\end{array}$ & Female & 68 & 63.0 & 64.8 & 100.0 \\
\hline & & & & & \\
\hline & Bachelor's Degree & 79 & 73.1 & 75.2 & 75.2 \\
\hline $\begin{array}{l}\text { Year since } \\
\text { graduation }\end{array}$ & Maser /Post Graduate Degree & 26 & 24.1 & 24.8 & 100.0 \\
\hline & & & & & \\
\hline & Less than 3 months & 6 & 5.6 & 5.7 & 5.7 \\
\hline & More than 3 to 6 months & 4 & 3.7 & 3.8 & 9.5 \\
\hline & More than 6 month to 1 year & 9 & 8.3 & 8.6 & 18.1 \\
\hline & More than 1 year to 2 years & 13 & 12.0 & 12.4 & 30.5 \\
\hline & More than 2 years & 73 & 67.6 & 69.5 & 100.0 \\
\hline
\end{tabular}

Tables 5 through 8 shows the results of the surveys that answer the following questions: What is the degree of satisfaction do MIS graduates have with their major? To what extend do MIS graduates believe that their major well prepared them to the job career/ market? To what extend do MIS graduates believe that their major well prepared them to the job career/ market? Do MIS graduate intent to recommend the MIS major to family members and friends? And To what extent do graduate students assess the importance and satisfaction of different skills acquired during the MIS curriculum (technical, analytical, interpersonal and communication)?

Table 5. The Degree of Satisfaction of MIS Graduates with Their Major

\begin{tabular}{|l|c|c|}
\hline & $\mathbf{N}$ & $\mathbf{\%}$ \\
\hline Strongly dissatisfied & 10 & 9.9 \\
\hline Dissatisfied & 13 & 12.9 \\
\hline Neutral & 23 & 22.8 \\
\hline Satisfied & 45 & 44.6 \\
\hline Strongly satisfied & 10 & 9.9 \\
\hline
\end{tabular}


Table 6. The Extent of MIS Graduates Believe that the Major Well Prepared Them for their Job

\begin{tabular}{|l|c|c|}
\hline & N & \% \\
\hline Strongly disagree & 4 & 3.9 \\
\hline Disagree & 14 & 13.6 \\
\hline Neutral & 25 & 24.3 \\
\hline Agree & 45 & 43.7 \\
\hline Strongly Agree & 15 & 14.6 \\
\hline
\end{tabular}

Table 7. MIS Graduate Intent to Recommend the MIS major to Family and Friends

\begin{tabular}{|l|c|c|}
\hline & N & \% \\
\hline Strongly disagree & 3 & 2.9 \\
\hline Disagree & 8 & 7.7 \\
\hline Neutral & 20 & 19.2 \\
\hline Agree & 40 & 38.5 \\
\hline Strongly Agree & 33 & 31.7 \\
\hline
\end{tabular}

Table 8. The Extent that Graduates are Satisfied of the Different Skills Acquired from MIS Curriculum

\begin{tabular}{|c|c|c|}
\hline & Mean & SD \\
\hline $\begin{array}{l}\text { My major could be improved by placing more emphasis on career oriented } \\
\text { learning }\end{array}$ & 4.00 & .625 \\
\hline $\begin{array}{l}\text { More input from business leaders about the direction of my major would } \\
\text { result in MIS improvement }\end{array}$ & 4.17 & .651 \\
\hline $\begin{array}{l}\text { Faculty teaching in my MAJOR should work more closely with business } \\
\text { leaders. }\end{array}$ & 4.14 & .761 \\
\hline
\end{tabular}

According to the above table we can notice that most of the participants were satisfied with their major, how well it prepared them and that they would recommend it to their family and friends. We can also notice even though the participants were satisfied but there was room for improvements such as to put some emphasis on career oriented learning, more input form business leaders about the direction of MIS major. In addition, faculty and business leaders should work closely in the academic arena.

\section{CONCLUSION}

This study contributes to the field through providing an overview of issues facing MIS graduates. This study used a combination of two research approaches (qualitative and quantitative) that makes this study unique. Results of both approaches show that sampled participants were both satisfied and dissatisfied, which leave room for improvement of the MIS curriculum. In addition, the misconception of MIS was an important finding of this study as it corroborates with results of past studies. Such findings call for more collaboration between academia and IT practitioners to define the MIS field and give it more recognition. A future research must take place to include perceptions of employers to see the adequacy/the fit between job required skills and those acquired by young MIS graduates. Without good knowledge of the skills needed by the employers, revisiting a curriculum might fall short of skills that must be included. Lastly, future studies needs to identify appropriate skills that MIS graduate need to possess in order to contribute to company improvements. 


\section{ACKNOWLEDGEMENTS}

This research was funded by Kuwait University, Research Grant RI 01/15. The author acknowledges the Research Administration Project for its support.

\section{REFERENCES}

Abraham, T., Beath, C., Bullen, C., Gallagher, K., Goles, T., Howland, J., Kaiser, K. \& M., J., Simon, J. (2006). IT workforce trends: Implications for IS programs. Communications for the Association for Information Systems, 17(50), pp. 1147-1170, 2006. Accessed January 19, 2010 from http://aisel.aisnet.org/cais/vol17/iss 1/50

Al-Imamy S. \& Farhat N. (2005). The MIS expectation gap in the UAE: Industry expectations versus academic Preparation. Journal of American Academy of Business, 7(2), pp. 78-85 (see web site:

http://www.sharjah.ac.ae/English/Academics/Colleges/BusinessAdmini/Departments/Managementit/Research/Pages /Publications.aspx

Benamati J. \& Rajkumar T.M. (2013). Undergraduate student attitudes toward MIS: Instrument development and changing perceptions of the field across gender and time. Communications of the Association for Information Systems, 33, pp. 241-266.

Buarki, H., Hepworth M., \& Murray I. (2011). Stakeholders' perspectives of LIS students' ICT skills in Kuwait, Proceeding of the KCESS '11 Proceedings of the Second Kuwait Conference on e-Services and e-Systems, Article No. 9.

Dick G.M., Luftman G., Slyke J. Van, \& Watson, R. (2007). Information Systems enrollments: Can they be increased? Communications of the Association for Information Systems, 20(41) 2007, http://aisel.aisnet.org/cais/vol20/iss1/41/, accessed January 19, 2010.

Green G.I. (1989). Perceived importance of systems analysts' job skills, roles and non-salary incentives. MIS Quarterly, 13(2), pp. 115-133.

Huang H., Kvasny, L., Joshi K.D., Trauth E.M. \& Mahar J. (2009). Synthesizing IT job skills identified in academic studies, practitioner publications and job ads. Proceedings of the ACM SIGMIS Computer Personnel Research Conference, Limerick, Ireland, May 28-30.

Joshi K. D., Kvasny L., McPherson S., Trauth L., Kulturel-Konak S., \& Mahar J. (2010). Choosing IT as a career: Exploring the role of self-Efficacy and perceived importance of IT skills, International Conference on Information Systems 2010.

Pepper T. (2007). MEED Employment survey: Unlocking potential. Meed 14-20 September 2007; pp. 4-7, http://www.meed.com/sectors/economy/meed-employment-survey-unlocking-potential/281487.article

Radermacher A., \& Walia G. (2013). Gaps between industry expectations and the abilities of graduates. Proceeding SIGCSE '13 Proceeding of the 44th ACM technical symposium on Computer Science Education, pp. 525-530.

Radmermacher A., Walia G., \& Knudson D. (2014). Investigating the skill hap between graduating students and industry expectations. Proceeding ICSE Companion 2014 Companion Proceedings of the 36th International Conference on Software Engineering, pp. 291-300.

Rouibah K., (2012), Understanding student drivers and obstacles toward MIS major from the perspective of an Arab country: The case of Kuwait. Issues in Information Systems Volume, 13(2), pp. 58-71, www.iacis.org/iis/iis.php

Simmons C.B. \& Simmons L.L. (2010) Gaps in the computer science curriculum: An exploratory study of industry professionals. Journal of Computing Sciences in Colleges 25(5), pp. 60-65. 